\title{
Publikacje romanistyczne W Akademii Wileńskiej w latach 1644-1655
}

\section{Uwagi wprowadzające}

Akademia Wileńska była drugą po Akademii Krakowskiej uczelnią na ziemiach polskich. Funkcjonowała ona z mocy przywileju wydanego przez króla Stefana Batorego z 7 lipca 1578 r. ${ }^{1}$, potwierdzonego bullą papieża Grzegorza XIII z 29 października 1579 r. $^{2}$ oraz uchwałą sejmową przyjętą

${ }^{1}[\ldots]$ et in collegio Vilnensi neque in medicina neque in iure civili, sed in artibus et philosophia promotiones sint faciendae, Archivum Romanum Societatis Iesu [dalej: ARSI], dział Lithuanica 36 f., 247 v; „Przywilej króla Stefana (Batorego) dany jezuitom kolegium wileńskiego, we Lwowie 7 lipca roku 1578, na ustanowienie Akademii w Wilnie, gabinetowy, tak zwany kieszonkowy, potrzebujący potwierdzenia stanów Rzeczypospolitej na sejmie...". W: M. Baliński: Dawna Akademia Wileńska. Petersburg 1862, s. 416; Archiwum Polskiej Akademii Nauk, maszyn. III-83, j. 9, Materiały Janiny Iwaszkiewicz, Uniwersytet Wileński. Teksty $i$ wypisy źródłowe dotyczace Uniwersytetu Wileńskiego, k. 2. Zob. J. Wisłocki: Prawo rzymskie $w$ Polsce. Warszawa 1945, s. 52; V. Lyavshuk: Stephan Bathory and the Jesuitsin Grodno: First Attempt to Found a Collegium. „Medieval and Early Modern Studies for Central and Eastern Europe" 2010, Vol. 2, s. 196.

${ }^{2}$ [...] in dicto collegio Studium generale theologiae et pro illius cognitione necesaria artium liberalium et philosophiae... tenore praesentium erigimus et instituimus. [...] Quod illi qui in quavis aliarum universitatum disciplinis, facultatibus et artibus praefatis studere incoeperint, studium suum in ea continuare, et tam ipsi quam et qui in dieta vel alia universitate per tempus debitam studuisse ac scientia et moribus idonei comperti fuerint, in artibus, philo- 
w $1585 \mathrm{r}^{3}$. W ramach Akademii Wileńskiej brakowało wydziału prawa, który został utworzony przez króla Władysława $\mathrm{IV}^{4}$ dopiero 11 października $1644 \mathrm{r}$. Nowa jednostka organizacyjna uczelni miała się składać z dwóch katedr prawa kanonicznego i dwóch katedr prawa cywilnego, czyli rzymskiego5. W związku $\mathrm{z}$ tak ukształtowaną wewnętrzną organizacją fakultetu istotną na nim rolę mieli odgrywać romaniści i kanoniści. Wydział Prawa w latach 1644-1655 przeżywał okres dynamicznego rozwoju. Prężny rozkwit uczelni i fakultetu został przerwany przez wydarzenia polityczne epoki, a mianowicie najazd moskiewski i potop szwedzki ${ }^{6}$.

sophia ac theologia neenon facultatibus praefatis, baccalaureatus, etiam formalis, licentiaturae ac laureae neenon doctoratus ac magisterii ac quoscumque alios solitos gradus ab ipsius universitatis rectore seu cancellano aut doctoribus, leetoribus vel aliis personis... recipere. Zob. Bultarum, diplomatum et privilegiorum sanetorum Romanorum Pontificum Taurinensis editio. Vol. 8. Torinas 1863, f. 561—562; Bulla Grzegorza XIII Najwyższego Pasterza. Wyjęta z rzymskiego bullariusza. C. II. W: M. Baliński: Dawna Akademia Wileńska..., s. 427.

${ }_{3}^{3}$ Akt fundacji i uposażenia Akademii Wileńskiej przez Waleriana Protasiewicza, biskupa wileńskiego uczyniony 24 sierpnia 1578 roku, a potwierdzony przez króla Stefana Batorego, naprzód w Wilnie 1 kwietnia 1579 roku, potem zaś za zgoda wszystkich stanów powtórnie na sejmie w Warszawie 23 lutego 1585 roku. W: M. Baliński: Dawna Akademia Wileńska..., s. 417 i nast. Zob. S. Bednarski: Geneza Akademii Wileńskiej. W: Księga pamiątkowa ku uczczeniu CCCL rocznicy założenia i X wskrzeszenia uniwersytetu Wileńskiego. T. 1. Wilno 1929, s. 290. Zob. także: L. Janowski: Historiografia Uniwersytetu Wileńskiego. Cz. 1. Wilno 1921, s. 8; J. Wisłocki: Prawo rzymskie..., s. 52.

${ }^{4}$ Przywilej Władysława IV dany Jezuitom Kolegium Wileńskiego, w Warszawie, w roku 1641, dnia 11 października, na publiczne wykładanie w Akademii Wileńskiej prawa kanonicznego i cywilnego oraz medycyny. W: M. Baliński: Dawna Akademia Wileńska..., s. 461 i nast.; M. Baliński: 1578-1803-1919. „Dziennik Wileński” 1919, T. 145, s. 3.

${ }^{5}$ Concedimus ut in praenominata Akademia Vilnensi Societatis Jesu Ius Canonicum ae Civile et Medicina publice praelegi possint, et ut quiennque digni iudicati fuerint in eisdem omnibus facultatibus... promoveri valeant ad gradus omnes in aliis Academiis et Universitatibus solitos conferri. Zob. J. Bieliński: Uniwersytet Wileński (1579-1831). T. 2. Kraków 1900, s. 476; L. Janowski: Historiografia Uniwersytetu Wileńskiego..., s. 9; S. Bednarski: Dwieście lat Wileńskiej Akademii Jezuickiej 1570-1773. W: Pamiętnik VI powszechnego zjazdu historyków polskich $w$ Wilnie 17-20 września 1935 r. Red. F. Podhorodecki. Cz. 1. Lwów 1935, s. 291; J. Wisłocki: Prawo rzymskie..., s. 52. Por. I. Petrauskienė: Dèl medicinos ir teisès katedru isteigimo Vilniaus akademijoje XVIII a. pradžioje. „Lietuvos Istorijos Metraštis” 1974 Metai, 1976, s. 104; V. Bogusis: Medicina Vilniaus Universitete XVI-XVII amziuje. „Mokslas ir Gyvenimas” 1979, Vol. 10, s. 26 i nast.; L. Piechnik: Dzieje Akademii Wileńskiej. T. 2: Rozkwit Akademii Wileńskiej w latach 1600-1655. Rzym 1982, s. 162-163.

${ }^{6}$ Annuae Litterae Collegii Vilnensis Societatis Iesu 1655, Archivum Romanum Societatis Iesu (ARSI) dział Lithuanica 40 f. 92. Zob. L. Piechnik: Dzieje Akademii Wileńskiej..., s. 263 i nast. 


\section{Claves juris Benedykta de Soxo}

$\mathrm{Na}$ uwagę zasługuje rozprawa Benedykta (Benito) de Soxo (Sojo), rektora Akademii Wileńskiej ${ }^{7}$, pod tytułem: Claves juris wydana w roku 1648, przeznaczona dla młodzieży studiującej prawo ${ }^{8}$. Sam autor pracy był związany z Wilnem i Uniwersytetem od roku 1624. W strukturach Academia Societatis Jesu Benedykt de Soxo piastował liczne godności, a mianowicie: doradcy (konsultora) rektora kolegium, prefekta — kierownika studiów wyższych w Akademii, jej kanclerza czy dwukrotnie wicekanclerza. Równocześnie jako znawca prawa kanonicznego kierował on rozwiązywaniem kazusów moralnych (praefectus casuum), pomagając młodym księżom w zdobywaniu wiedzy teoretycznej i praktycznej z dziedziny teologii moralnej i sakramentu spowiedzi. Ponadto pełnił funkcję regensa seminarium papieskiego i diecezjalnego w Wilnie. Benedykt de Soxo prowadził ożywioną działalność w zakonie jezuitów jako doradca Fabritiusa Banfiego, wizytatora prowincji litewskiej czy wreszcie samego prowincjała. W 1643 r. Benedykt de Soxo został rektorem Akademii Wileńskiej, która pod jego rządami przeżywała jeden z najświetniejszych okresów swej historii. W murach Academia Vilnensis gościł króla Władysława IV z żoną Cecylią Renatą z Habsburgów9 . Benedykt de Soxo przyczynił się do powstania Wydziału Prawa Akademii Wileńskiej. W Academia Vilnensis prowadził także ożywioną działalność naukową i dydaktyczną jako wykładowca teologii scholastycznej. Zajęcia $\mathrm{z}$ tej dyscypliny prowadził z krótkimi przerwami do roku 1631. O tym, że był cenionym i uznanym wykładowcą, może świadczyć zachowany rękopis jego wykładów z 1626 r. pod tytułem: Tractatus de venerabili Eucharistiae sacramento... ${ }^{10}$. Jest to gruntowne studium teologiczne oparte $w$ dużej mierze na nauce św. Tomasza z Akwinu. Benedykt de Soxo przywołuje w nim licznych autorów hiszpańskich, których twórczość niewątpliwie pochodzący z Grenady naukowiec musiał doskonale znać. W 1625 r., po uroczystej publicznej dyspucie, otrzymał on doktorat $\mathrm{w}$ zakresie teologii ${ }^{11}$. Benedykt de Soxo przygotował Praecepta grammaticae linguae Polonicae z przeznaczeniem dla obcokrajowców

${ }^{7}$ Encyklopedia wiedzy o jezuitach na ziemiach Polski $i$ Litwy 1564-1995. Oprac. L. Grzebień. Kraków 2004, s. 634.

${ }^{8}$ Claves iuris Academicis Vilnensibus a R. P. Benedicto de Soxo S. I. sacrae theologiae doctore et Academiae vicecancellario porrectae. Vilniae Typis Academicis Societatis Iesu 1648.

${ }^{9}$ Zob. L. Grzebień: Soxo (Sojo) Benedykt (Benito). W: Polski stownik biograficzny. T. 41. Kraków 2002, s. 24-25. Por. S. Załęski: Jezuici w Polsce. T. 2: Jezuiccy pisarze 1608-1648. Lwów 1901, s. 699-700; Historia nauki polskiej. Red. B. Suchodolski. T. 6: Dokumentacja bio-bibliograficzna. Oprac. L. Hajdukiewicz. Wrocław 1974, s. 31; L. Piechnik: Soxo (Sojo) Benedykt de. W: Słownik polskich teologów katolickich. Red. H.E. Wyczawski. T. 4. Warszawa 1983 , s. $160-161$.

${ }^{10}$ Kungliga Biblioteket w Sztokholmie, Rkp. A 817, s. 36-127.

${ }^{11}$ L. Piechnik: Dzieje Akademii Wileńskiej..., s. 174. 
pracujących w Polsce. Gramatyka języka polskiego powstała około roku 1636, i z wielkim prawdopodobieństwem nigdy nie ukazała się drukiem ${ }^{12}$.

Nieznane są powody napisania przez Benedykta de Soxo Claves juris, pokaźnego dzieła (297 stron) adresowanego do studentów Wydziału Prawa Akademii Wileńskiej. Zdaniem Ludwika Piechnika, rektor Akademii Wileńskiej stworzył swoją pracę w związku z wykonywaniem funkcji resolutor casuum. Sugerował, że Benedykt de Soxo w swej rozprawie przygotował i przedstawił wobec profesorów i słuchaczy Alma Mater różne aktualne problemy z dziedziny teologii moralnej i prawa kościelnego. Następnie ten sam zabieg miał powtórzyć w odniesieniu do słuchaczów Wydziału Prawa, chociaż sam tam nie wykładał ${ }^{13}$. Nie do końca można podzielić poglądy Ludwika Piechnika. Na odwrocie strony tytułowej Ad lectorem autor Claves juris stwierdza, że Lew Sapieha ufundował w Wilnie katedrę prawa, a on sam napisał dzieło, które przeznacza dla młodzieży tam studiującej ${ }^{14}$.

W nauce, co prawda, dominuje pogląd, że Benedykt de Soxo był teologiem ${ }^{15}$. Jednakże bardziej prawdziwa może okazać się teza Michała Balińskiego ${ }^{16}$, ostatnio przywołana przez Mikołaja Tarkowskiego ${ }^{17}$, że pochodzący z Grenady rektor Akademii Wileńskiej nauczał prawa kanonicznego. Niewątpliwie Benedykt de Soxo nie był romanistą, chociaż znał kodyfikację justyniańską, o czym świadczą liczne powołania się na Corpus Iuris Civilis w Claves juris. Tadeusz Pawluk wymieniał go wśród czterech pierwszych profesorów Akademii Wileńskiej obok Aarona Aleksandra Olizarowskiego, Szymona Dilgera i Jana Jerzego Schauera ${ }^{18}$. Wnikliwa analiza dzieła napisanego przez rektora Academia Vilnensis może wskazywać, że istotnie mógł być specjalistą z zakresu prawa kanonicznego i pracować na Wydziale Prawa Akademii Wileńskiej.

Claves juris Benedykta de Soxo to praca, w której autor omawia różne porządki prawne. Rozprawa zawiera w sobie nieponumerowane karty, co, zda-

12 Zob. S. Rostowski: Lituanicarum Societatis Jesu historiarum libri decem. Recogn. J. Martinov. Parisiis 1877, s. 456; L. Grzebień: Soxo (Sojo) Benedykt (Benito)..., s. 24 i nast.

${ }^{13}$ L. Piechnik (Dzieje Akademii Wileńskiej..., s. 176) uważał, że katalogi kolegium w Wilnie nie wspominają, by Benedykt de Soxo nie został w nich wyszczególniony jako profesor prawa. Ponadto twierdził, że w czasie gdy powstawał Wydział Prawa, pełnił on funkcję rektora, a następnie poważnie zachorował.

${ }^{14}$ Claves iuris Academicis Vilnensibus..., s. 2.

${ }^{15} \mathrm{Na}$ to wskazują słowniki i encyklopedie. Zob. Filozofia i myśl społeczna XVII wieku. Cz. 1. Red. Z. Ogonowski. Warszawa 1979, s. 261-279; S. Jedynak: Etyka w Polsce. Stownik pisarzy. Wrocław 1986, s. 130; Encyklopedia wiedzy o jezuitach..., s. 473-474.

${ }^{16}$ M. Baliński: Dawna Akademia Wileńska..., s. 147. Zob. także J. Bieliński: Uniwersytet Wileński..., s. 475; S. Załęski: Jezuici w Polsce..., s. 640; A. Petrani: Nauka prawa kanonicznego w Polsce w XVIII i XIX wieku. Lublin 1961, s. 204.

${ }_{17}$ M. Tarkowski: Wydziat Prawa i Nauk Spolecznych Uniwersytetu Stefana Batorego $w$ Wilnie w latach 1919-1939. Gdańsk 2015, s. 28.

${ }_{18}$ T. Pawluk: Z zagadnień kanonistyki polskiej. „Prawo Kanoniczne” 1976, nr 19, z. 3-4, s. 184. 
niem jej twórcy, ma obciążać niesolidnego drukarza. Na właściwą treść dzieła składa się szereg rozpraw zatytułowanych Claves. Swoje wywody zaczyna Benedykt de Soxo od omówienia pojęć, podziałów, jako również źródeł prawa kanonicznego, cywilnego (rzymskiego) oraz miejscowego. Bardzo istotnym zagadnieniem, które opisał autor Claves juris, są fundamenty zarówno prawa naturalnego, jak i pozytywnego. Pod tym ostatnim pojęciem rozumiał Benedykt de Soxo prawo kanoniczne, cywilne (rzymskie) oraz prawa Rzeczypospolitej, wśród których wyróżniał prawo magdeburskie. Ważne miejsce w jego publikacji zajmuje właściwie stosowana interpretacja prawna, która została wyodrębniona w coś w rodzaju rozdziału. Kolejna jednostka redakcyjna pracy dotyczy władzy sądowej i legislatywnej, chociaż Benedykt de Soxo w tym miejscu swojej rozprawy odnosił się prawie wyłącznie do ustawodawstwa władz kościelnych. Dalsze części dzieła Claves juris to: $O$ rubrykach ustaw, O proaemium legis, O glosach czy $O$ nazwach nadawanych ustawom. Ważne miejsce w publikacji Benedykta de Soxo zajmuje jednostka redakcyjna odnosząca się do autorytetu uczonych. Przytaczał, w treści swego dzieła, szereg znanych i uznanych opinii teologów, kanonistów i filozofów, a w szczególności poglądy Augustyna Barbosy ${ }^{19}$, zwanego „księciem wśród kanonistów”20. Benedykt de Soxo dość często cytował prace współczesnych mu pisarzy i myślicieli, głównie związanych z jezuitami. W Claves juris zostały omówione także różne formułki, zwroty, klauzule czy wyrazy techniczne (series nominum appelativorum) używane przez prawników. Rektor Akademii Wileńskiej rozpoczynał swoje wywody, w każdej z poruszanych materii, od odniesienia się do prawa rzymskiego. Praca Benedykta de Soxo zawiera mało treści teoretycznych ${ }^{21}$. Rektor Akademii Wileńskiej kończy swoje dzieło praktycznymi radami dla studentów Wydziału Prawa (Generales ultimae ad praxim studenti juris).

Pomimo że Benedykt de Soxo nie był romanistą, analiza treści rozprawy wskazuje na gruntowną znajomość jej autora zasad, systematyki i instytucji prawa cywilnego (rzymskiego). Świadczy również o predyspozycjach jej twórcy do nauczania prawa kanonicznego na Wydziale Prawa.

${ }^{19}$ L. Piechnik: Dzieje Akademii Wileńskiej..., s. 175.

${ }^{20}$ J. Mandziuk: Księgozbiór Melchiora kardynała Diepenbrocka, księcia-biskupa wroclawskiego (1798-1853). „Saeculum Christianum” 2004, nr 11, z. 1, s. 74.

${ }^{21}$ I. Petrauskienè: Del medicinos..., s. 95 i nast.; K. Estreicher: Bibliografia polska. Cz. 3: Bibliografia wieków XV-XVIII w układzie abecadłowym. T. 29. Warszawa 1977, s. 9899 obecnie w Elektroniczna Baza Bibliografii Estreichera (EBBE) https://www.estreicher.uj.edu. $\mathrm{pl} /$ staropolska/indeks/wpis/?id=46539\&fileId $=0115$. 


\section{De politica hominum societate Aarona Aleksandra Olizarowskiego}

Od początku funkcjonowania Wydziału Prawa wykładowcą prawa w Akademii Wileńskiej był również Aaron Aleksander Olizarowski ${ }^{22}$. Prawnik przybył do stolicy Wielkiego Księstwa Litewskiego w 1644 r. $^{23}$. Poza prowadzeniem dydaktyki wypromował dwóch doktorów utriusque iuris ${ }^{24}$.

Jako profesor prawa Aaron Aleksander Olizarowski (Olizarovio iurium doctor et eorundem in Alma Universitate Vinnensi profesore ordinario) wydał w Gdańsku w 1651 r. dzieło swego życia: De politica hominum societate — systematyczny wykład wiedzy o społeczeństwie i państwie ${ }^{25}$. Autor podjął się napisania pracy o dość szeroko i ogólnie zakreślonym temacie. De politica hominum societate nawiązywało do tradycji pism społeczno-politycznych poprzednich epok, a w szczególności do kierunku naukowego zwanego arystotelizmem ${ }^{26}$. Stąd też liczne odwołania w pracy Olizarowskiego do dzieł Arystotelesa i do jego Polityki $i^{27}$.

Rozprawa charakteryzowała się dość przejrzystą strukturą i składała się z zagadnień wstępnych (Questiones proemiales) oraz trzech ksiąg: De Domo, De Civitate oraz De republica. Dzieło De politica hominum societate było przedmiotem zainteresowania i analizy badaczy różnych dziedzin i dyscyplin

${ }^{22}$ E. Jarra: Aleksander Olizarowski, jako filozof prawa. W: Księga pamiątkowa celem uczczeniu 350 rocznicy założenia Uniwersytetu Stefana Batorego w Wilnie. Warszawa 1931, s. 33-72; S. Kot: Aaron Aleksander Olizarowski, profesor prawa Akademii Wileńskiej. W: Księga pamiątkowa ku uczczeniu CCCL rocznicy założenia i X wskrzeszenia Uniwersytetu Wileńskiego. Wilno 1929, s. 6 i nast.; P. Niczy poruk: Nauczanie prawa rzymskiego w Akademii Wileńskiej. W: Wielokulturowość polskiego pogranicza. Ludzie - idee - prawo. Materiaty ze Zjazdu Katedr Historycznoprawnych Augustów 15-18 września 2000 r. Red. A. Lityński, P. Fiedorczyk. Białystok 2003, s. 152 i nast.

${ }^{23}$ Świadczyć o tym może list Aarona Aleksandra Olizarowskiego do Kazimierza Lwa Sapiehy z 26 września 1644, znajdujący się w Bibliotece Czartoryskich, którego tłumaczenie publikuje L. Piechnik: Dzieje Akademii Wileńskiej..., s. 169-171. Zob. E. Ulčinaitè: Vilniaus akademijos profesorius A. Olizarovijus. „Mokslas ir gyvenimas” 1978, Vol. 5, s. 16; S. Pyszka: Il diritto alla libertà personale e alla cittadinanza dei contadini polacchi e lituani in Aron Aleksander Olizarowski (1610-1659). „Forum Philosophicum” 2002, T. 7, s. 207.

${ }^{24}$ P. Niczy poruk: Aaron Aleksander Olizarowski profesorem prawa Akademii Wileńskiej. „Miscellanea Historico-Iuridica” 2015, T. 14, z. 2, s. 185 i nast.

${ }^{25}$ E. Jarra: Aleksander Olizarowski..., s. 33-72; A. Tamošiūnienè: Lietuvos sprendimai ir Naujausiuju laiku skaitytojas. „Senoji Lietuvos Literatūra” 2008, Vol. 25, s. 284.

${ }^{26}$ P. Rybicki: Z dziejów polskiego arystotelizmu: De politica hominum societate Arona Aleksandra Olizarowskiego. „Studia i Materiały z Dziejów Nauki Polskiej”, Seria A: Historia nauk społecznych 1959, z. 3, s. 90 i nast.

27 S. Kot: Aaron Aleksander Olizarowski..., s. 4. 
nauki ${ }^{28}$. Warto więc dokonać analizy De politica hominum societate, mając na względzie jedynie perspektywę romanistyczną.

Księga pierwsza - De Domo - zawierała dwanaście rozdziałów o różnym zakresie i objętości ${ }^{29}$. Treściowo odnosiła się do trzech istotnych zagadnień, a mianowicie: małżeństwa, rodziny i poddaństwa. Posługując się cytatami z literatury antycznej, Olizarowski wyjaśniał czytelnikowi cele małżeństwa oraz jego konsekwencje w ujęciu prawa rzymskiego i kanonicznego. Szczególnie wiele miejsca zajmowało odniesienie się autora De politica hominum societate do problematyki związanej z przeszkodami małżeńskimi. Omawiał tam kwestie dotyczące wieku nupturientów oraz zagadnienia secundae nuptiae wdowy. Olizarowski w kilku kolejnych rozdziałach odniósł się do obowiązków małżeńskich. Autor De politica hominum societate przyznał mężowi władzę nad żoną, zalecając mu miłość i szacunek względem małżonki. Żona winna być posłuszna mężowi i nie uzurpować sobie władzy w małżeństwie ${ }^{30}$. Twórca De politica hominum societate omówił kary za cudzołóstwo, pokazując ich romanistyczny rodowód.

Olizarowski prowadził ciekawe rozważania odnośnie do problematyki stosunków między rodzicami a dziećmi. Romanistów może interesować paragraf dziewiętnasty traktujący o władzy ojcowskiej nad dziećmi (de patria in liberos potestato). Olizarowski pojmował władzę ojcowską jako prawo ojca nad osobą i mieniem dziecka ${ }^{31}$. Ostatni dwudziesty paragraf księgi pierwszej odnosił się

${ }^{28}$ Ibidem, s. 4; E. Jarra: Aleksander Olizarowski..., s. 33-72; P. Rybicki: Pojęcie spoŁeczności u pisarzy polskiego odrodzenia. „Studia i Materiały z Dziejów Nauki Polskiej”, Seria A: Historia nauk społecznych 1957, z. 1(5), s. 3-44; Idem: Z dziejów polskiego arystotelizmu..., s. 83-136; J. Tazbir: Thomas More in Poland. „Acta Polonia e Historica” 1976, T. 33, s. 16; R. Plečkaitis: Filozofia prawa w dawnym Uniwersytecie Wileńskim. W: Philosophia vitam alere. Prace dedykowane Księdzu Profesorowi Romanowi Darowskiemu SJ z okazji 70-lecia urodzin. Red. S. Ziemiański SJ. Kraków 2005, s. 513 i nast.; S. Pyszka: Il diritto alla libertà..., s. 233.

${ }^{29}$ Znajdziemy tam rozdziały liczące trzy strony oraz mające po kilkadziesiąt stron objętości podzielone na paragrafy i sekcje. Zob. P. Rybicki: $Z$ dziejów polskiego arystotelizmu..., s. 92 i nast.

30 A.A. Olizarovio: De politica hominum societate. Gdańsk 1651, s. 64.

31 Zob. na ten temat odnośnie do prawa rzymskiego ostatnio pisali: M. Zabłocka: Przemiany prawa osobowego i rodzinnego w ustawodawstwie dynastii julijsko-klaudyjskiej. Warszawa 1987, s. 34 i nast.; J. Zabłocki: „Consortium ercto non cito” w „Noctes Atticae” Aulusa Gelliusa. „Prawo Kanoniczne” [dalej: PK] 1988, z. 4, s. 271; Idem: Kompetencje „patres familias” i zgromadzeń ludowych w'świetle „Noctes Atticae” Aulusa Gelliusa. Warszawa 1990, s. 29 i nast.; Idem: Rodzina rzymska w świetle „Noctes Atticae” Aulusa Gelliusa. W: Rodzina $w$ społeczeństwach antycznych $i$ wczesnym chrześcijaństwie. Literatura, Prawo, epigrafika, sztuka. Red. J. Jundziłł. Bydgoszcz 1995, s. 45; J. Zabłocki: The Image of a Roman Family in „Noctes Atticae” by Aulus Gellius. „Pomoerium. Studia et Commentarii Ad Orbem Classicum Spectantia" 1996, Vol. 2, s. 48 i nast.; A. Nowak [Jurewicz]: Pojęcie władzy ojcowskiej w rzymskim prawie klasycznym. „Studia Prawnoustrojowe” 2002, nr 1, s. 48 i nast.; P. Niczyporuk: Kompetencje pater familias względem dzieci w ustawach królewskich (leges regiae) 
do obowiązków dzieci względem rodziców (de liberorum erga parentes officio) i przewidywał kary za ich zaniedbanie. Omawiając zagadnienia związane z władzą ojcowską, autor przytaczał opinie prawników rzymskich oraz prace komentatorów. Olizarowski odwoływał się także do antykwarysty Gellusa, cytując jego poglądy na małżeństwo i rodzinę $e^{32}$. Autor De politica hominum societate wyróżnił okres dziecięcy - infantia - trwający od urodzenia do 7. roku życia, tożsamy $\mathrm{z}$ uznanym $\mathrm{w}$ prawie rzymskim okresem dzieciństwa ${ }^{33}$. Przy omawianiu tych zagadnień nieodzowne było jego romanistyczne wykształcenie. Kolejny, wskazany przez Olizarowskiego, okres życia człowieka, a mianowicie od 7. do 14. roku życia może wskazywać na znany prawu rzymskiemu okres niedojrzałości (impuberes) ${ }^{34}$.

Trzecią część pierwszej księgi stanowiły relacje De Domino et Servo, gdzie Olizarowski analizował zagadnienia dotyczące wolności, niewolnictwa i poddaństwa. Rozważania w tej materii autora De politica hominum societate nie były wolne od odniesień do prawa rzymskiego, jak również i do stosunków gospodarczych i społecznych panujących w starożytnym Rzymie. Olizarowski omawiał położenie chłopów przez porównanie z rzymskimi kolonami (adscriptitii

w starożytnym Rzymie. W: Mężczyzna, etyka, ekonomia. Red. E. Ozorowski, R.C. Horodeński. Białystok 2011, s. 179 i nast.

32 A.A. Olizarovio: De politica hominum..., s. 151. O Gelliusie pisał J. Zabłocki: „Consortium recto non cito”..., s. 271-182; Idem: Kompetencje „pater familias”..., passim; Idem: Talion w świetle „Noctes Atticae” Aulusa Gelliusa. PK 1995, z. 3-4, s. 231-244; Idem: Rodzina rzymska $w$ świetle „Noctes Atticae”..., s. 45-57; Id em: The Image a Roman Family..., s. 47-58; Idem: „Postumus” w „Noctes Atticae” Aulusa Gelliusa. PK 1997, z. 1-2, s. 255262; Idem: Rozważania o procesie rzymskim w „Noctes Atticae” Aulusa Gelliusa. Warszawa 1999, passim; Idem: Appunti sull' „officium iudicis” nelle „Noctes Atticae”. In: Au-delà des fontierès. Mélanges de droit romain offers à Witold Wołodkiewicz. T. 2. Varsovie 2000, s. 1115-1126; Idem: Ze studiów filozofii Aulusa Gelliusa w Atenach. W: Profesorowi Janowi Kodrębskiemu ,in memoriam”. Red. A. Pikulska-Robaszkiewicz. Łódź 2000, s. 465-474; Idem: The Intellectual Background of Aulus Gellius. „Diritto@Storia. Rivista internazionale di Scienze Giuridiche e Tradizione Romana" 2007, T. 6; Idem: Rzymskie Studia Aulusa Gelliusa. „Acta Universitatis Wratislaviensis”. Prawo 2008, nr 305: Studia historycznoprawne. Tom poświęcony pamięci Profesora Edwarda Szymoszka. Red. A. Konieczny, s. 425-433.

33 A. Berger: Encyclopedic Dictionary of Roman Law. Philadelphia 1953 (przedruk 1991), s. 495, s.v. Impubes. Szerzej zob. F. Wycisk: Obowiazki alimentacyjny $i$ wychowawczy w prawie rzymskim okresu królewskiego. „Roczniki Teologiczno-Kanoniczne” 1963, T. 10, z. 4, s. 234; G. Impallomeni: Persona fisica. Diritto romano. „Novissimo Digesto Italiano” 1965, Vol. 12, s. 1028 i nast. \{= Scritti di diritto romano e tradizione romanistica. Padova 1996, s. 133 i nast.\}. Por. G. Kuleczka: Dzieci w systemie prawnym starożytnego Rzymu. „Meander” 1979, z. 5-6, s. 237-250; Idem: Prawo rzymskie epoki pryncypatu wobec dzieci pozamatżeńskich. Wrocław-Warszawa-Kraków 1969, s. 64 i nast.

${ }^{34}$ A. Berger: Encyclopedic Dictionary..., s. 495, s. v. Impubes. Szerzej zob. A. Burdesse: Sulla capacita intellettuale degli impuberes in diritto classico. „Archivio Giuridico Filippo Serafini" 1956, T. 150 , s. $10-66$. 
servi dicebantur coloni, qui glebae, aut terrae.... $)^{35}-$ glebae ascripti $^{36}$. W Cesarstwie Rzymskim byli to dzierżawcy gruntów, którzy początkowo posiadali wolność. Jednakże od 332 r. n.e. zostali oni dziedzicznie przypisani do ziemi, wraz z którą mogli być sprzedani ${ }^{37}$.

Olizarowski, odnosząc się do zagadnienia wolności, zdawał sobie sprawę z wieloznaczności tego terminu. Rozpatrywał go w kontekście filozoficznym, politycznym i prawnym. Posługując się literaturą, także romanistyczną, wskazywał na różne przyczyny i rodzaje niewolnictwa. Niewątpliwie księga zawierała w sobie najwięcej odniesień do prawa rzymskiego. W dalszych rozdziałach De politica hominum societate Olizarowski w mniejszym stopniu prezentował swój romanistyczny warsztat.

Zasadniczym przedmiotem rozważań w księdze drugiej noszącej tytuł $\mathrm{De} C \mathrm{C}$ vitate była problematyka społeczności obywatelskiej (państwowej). Olizarowski przeprowadził terminologiczne refleksje w zakresie pojęcia civitas, nie stroniąc od rzymskich wątków związanych z zagadnieniem obywatelstwa. Wypadkową tych rozważań była kwestia sprawowania urzędów i obowiązki obywatelskie. Dalsze rozdziały księgi poświęcone sądom i prawom także miały odniesienia do prawa rzymskiego. Szkoda jedynie, że piszący je profesor prawa potraktował te zagadnienia dość skrótowo. W księdze tej dostrzegamy istotne dysproporcje w omawianej materii. I tak, kwestie dotyczące stanu szlacheckiego zostały szerzej omówione niż te odnoszące się do prawa i sprawowania urzędów ${ }^{38}$.

W księdze trzeciej zatytułowanej De Republica mamy najmniej odniesień do prawa rzymskiego. Jest to zrozumiałe ze względu na omawianą materię dotyczącą państwa (respublica), jego pochodzenia oraz uwarunkowań związanych $\mathrm{z}$ jego istnieniem. Także zagadnienia związane ze zmianami i przewrotami politycznymi nie stanowią zbyt dużego pola dla romanisty.

Niewątpliwie Olizarowski, przytaczając takie terminy jak: parentes, patrimonium, peculium, czy zwrot filia familias, odwoływał się do ich definicji (maxime juribus Romanis definita, explicant Juris interpretes ${ }^{39}$ zawartych w pięćdziesiątej księdze Digestów, w tytule szesnastym De verborum significatione ${ }^{40}$. Także posługiwał się definicją servitus, w znaczeniu podległości osobistej, zaczerpniętą

35 A.A. Olizarovio: De politica hominum..., s. 147.

${ }^{36}$ Por. W. Wolfarth: Ascripticii w Polsce. Wrocław-Kraków 1959, s. 42 i nast.

37 A. Berger: Encyclopedic Dictionary..., s. 351, s. v. Adscriptici. Szerzej zob. J. Kolendo: Kolonat w Afryce rzymskiej w I-II wieku I jego geneza. Warszawa 1962, passim; La M. De Dominicis: I coloni ,adscripticii” nella legislazione di Giustiniano. In: Studi in onore di Emilio Betti. Vol. 3. Milano 1962, s. 89 i nast.; B. Lapicki: La transformation de la nature juridique du colonat romain. In: Studi in onore di Edoardo Volterra. Vol. 3. Milano 1971, s. 359-373; M. Mirković: The Later Roman Colonate and Freedom. Philadelphia 1997, s. 65 i nast.

${ }^{38}$ P. Rybicki: $Z$ dziejów polskiego arystotelizmu..., s. 95 i nast.

39 A.A. Olizarovio: De politica hominum..., s. 137.

${ }^{40}$ D. 50, 16, 195. 
z prawa rzymskiego ${ }^{41}$. Olizarowski, omawiając status prawny osoby poniżej i powyżej 25. roku życia, czynił odniesienia do tytułu De statu hominum ${ }^{42}$ z Digestów ${ }^{43}$. Analizując zaś restitutio in integrum, wskazał tytuł De minoribus, błędnie podając jego numer (D. 4, 9) ${ }^{44}$. Natomiast kompilatorzy umieścili go w De minoribus viginti quinque annis w D. 4, 4. Olizarowski posługiwał się sformułowaniami ius Romanorum czy legis Romanorum, które mogą sugerować, że omawiane instytucje były zaczerpnięte z prawa rzymskiego ${ }^{45}$. Autor De politica hominum societate, by tak móc porównywać konstrukcje prawne różnych epok z tymi znanymi prawu rzymskiemu, musiał mieć gruntowną wiedzę w opisywanej materii i znajomość dostępnej literatury przedmiotu. Posługiwał się nie tylko wiedzą ogólną, wyniesioną ze studiów, ale operował bardziej szczegółowymi instytucjami prawnymi, które mogą być znane tylko specjaliście z danej dziedziny.

Aaron Aleksander Olizarowski, pisząc De politica hominum societate, wielokrotnie opierał się na znanych prawu rzymskiemu terminach, pojęciach i konstrukcjach prawnych. Wykorzystał on wiedzę zdobytą podczas studiów oraz doświadczenia z pracy ze studentami Akademii Wileńskiej. Pobieżna lektura De politica hominum societate może być dowodem, że Aaron Aleksander Olizarowski wykładał prawo cywilne (rzymskie) i kierował na Alma Mater Vilnensis stosowną katedrą.

\section{Dissertatio iuridica de damno injuria Jana Marquarta}

Nie ulega wątpliwości, że prawo rzymskie odgrywało istotną rolę nie tylko w kształceniu prawników i było wykładane z przerwami przez cały dalszy okres funkcjonowania Akademii ${ }^{46}$. Wzorem innych uniwersytetów Akademia Wileńska nadawała w tym zakresie połączony stopień doktora „obojga praw”: cywilnego (rzymskiego) i kanonicznego, o który ubiegali się przede wszystkim przyszli profesorowie prawa, a także wysocy dostojnicy kościelni, którzy wykonywali funkcje publiczne ${ }^{47}$.

${ }^{41}$ A.A. Olizarovio: De politica hominum..., s. 148-149 liber I, cap. XI.

${ }^{42}$ D. $1,5$.

43 A.A. Olizarovio: De politica hominum..., s. 149.

${ }^{44}$ Ibidem.

${ }^{45}$ Liber I, cap. XI.

${ }^{46}$ Por. L. Piechnik: Dzieje Akademii Wileńskiej..., s. 81; P. Niczyporuk: Nauczanie prawa rzymskiego..., s. 153.

${ }^{47}$ P. Niczy poruk: Promocje doktorskie obojga praw w Akademii Wileńskiej. „Miscellanea Historico-Iuridica” 2004, T. 2, s. 17-31. Por. H. Gmiterek: Promocje doktorskie w Akademii Zamojskiej. W: W kręgu akademickiego Zamościa. Red. H. Gmiterek. Zamość 1996, s. 225. 
W maju 1650 r. odbyła się publiczna obrona doktoratu jednego z pierwszych wychowanków Wydziału Prawa Alma Mater Vilnensis Jana Marquarta (Markwarta). Praca nosiła tytuł De damno injuriae ${ }^{48}$, który można tłumaczyć jako: „Dysertacja prawnicza na temat bezprawnie wyrządzonej szkody”. Promotorem rozprawy doktorskiej był Szymon Dilger ${ }^{49}$, który również stał na czele komisji powołanej do obrony doktoratu ${ }^{50}$. Dysertacja została napisana wyłącznie na podstawie prawa cywilnego (rzymskiego). Jest jedyną rozprawą $\mathrm{z}$ tej materii prawnej w Akademii Wileńskiej w latach $1644-1655^{51}$.

Pozostałe doktoraty z tego okresu miały charakter prawno-porównawczy lub napisano je w oparciu o kanoniczny porządek prawny. W roku 1647 trzech pierwszych doktorów utriusque iuris obroniło swoje prace. Pierwsza z nich to rozprawa Andrzeja Marquarta (Markwarta) zatytułowana Dissertatio juridica e jure canonico, civili et Regio Poloniae Magniq[ue] Ducatus Lithuaniae nec non Saxonico et municipali Magdeburgensi ${ }^{52}$. Było to dzieło o charakterze prawno-porównawczym, które uwzględniało podstawowe porządki prawne obowiązujące na terenie Wielkiego Księstwa Litewskiego ${ }^{53}$. Rozprawa obejmowała swym zakresem prawo spadkowe, zarówno dziedziczenie testamentowe, jak i beztestamentowe ${ }^{54}$. Autor dysertacji porównywał prawo cywilne (rzymskie)

${ }^{48}$ Dissertatio iuridica de damno iniuriae, quam proside Nobili et Clarissimo D[omino] Simone Dilger Morenweisensi Bavaro, I[uris] U[triusque] Doctore, et in Alma Universitate Vilnensi Soc[ietatis] Iesu Pandectarum Professore Ordinario defendendam suscepit pro obtinenda Doctoratus in eadem Facultate Laurea Ioannes Marquart A[rt]a[s] L[Ibera]l[es] et Philosophiae Magister Iuris Utriusque Auditor, Vilnae [Vilnius], Typis Academiciis S[ocietatis] I[esu]. Anno D[omin]ai. M.DC.L.(1650) Mense Maii Die.

${ }^{49}$ S. Kot: Aaron Aleksander Olizarowski.., s. 5; L. Piechnik: Dzieje Akademii Wileńskiej..., s. 172.

${ }^{50}$ I. Marquart: Dissertatio iuridica De damno iniurice. Vilnæ 1650, s. 1. Co prawda oryginał nie posiada numeracji stron, i nie wiadomo w związku $\mathrm{z}$ tym, skąd należałoby numerację zacząć dlatego też autor niniejszego artykułu na jego potrzeby dokonał własnej numeracji stron rozpoczynając od strony tytułowej.

${ }^{51}$ Zob. P. Niczyporuk: Dissertatio iuridica de damno injuriae Jana Marquarta, Vilnae 1650, pierwszym doktoratem z zakresu prawa rzymskiego $w$ Akademii Wileńskiej. W: Semperfidelis. Prace dedykowane pamięci Profesora Janusza Sondla - legendzie krakowskiego fakultetu prawniczego. Red. D. Malec, Ł. Marzec, T. Palmirski. Kraków 2017, s. 279-280.

${ }_{52}$ Dissertatio iuridica e iure canonico, civili et regio Poloniae, Magniq[ue] Ducatus Lithuaniae nec non Saxonico et municipali Magdeburgensi decisa quam sub felicissimis auspiciis Illustrissimi Domini D[omino] Casimiri Leonis Sapieha, M[agnique] D[ucatus] L[ithuaniae] Procancellarii, Stonimensis, Volpensis, Luboszanensis etc Gubernatoris in Alma Universitate Vilnensi Soc[ietatis] Jesu, Facultatis Iuridicae Fundatoris, praeside Nobili et Clarissimo D[omi] n[o] Joanne Georgio Schaver de Augenburg I[uris] U[triusque] Doctore et in eadem Universitate S[anti]s[ime] Canon[um] Ordinario Professore, / defendendam suscepit Andreas Marquart, AA.[Artium] LL.[Liberalium] et Philosophiae Magister et I[uris] U[triusque] Auditor. Vilnae [Vilnius], Typis Academicis Soc[ietatis] Iesu, Anno Domini MDCXLVII [1647]. die [22] Iunii.

${ }_{53}$ P. Niczy poruk: Promocje doktorskie..., s. 18 i nast.

${ }^{54}$ J. Bieliński: Uniwersytet Wileński (1579-1831). T. 3. Kraków 1900, s. 653. 
z innymi regulacjami obowiązującymi w tym czasie na obszarze Wielkiego Księstwa Litewskiego, ale nie była to praca w pełni romanistyczna.

W pierwszej części, odnoszącej się do sukcesji testamentowej, Andrzej Marquart swoje rozważania rozpoczął od znanej prawu rzymskiemu definicji testamentu. Wskazał romanistyczny rodowód zasady szacunku dla ostatniej woli zmarłego czy opisał podział testamentów na ustne i pisemne ${ }^{55}$. Rozważania autora Dissertatio juridica e jure canonico w odniesieniu do prawa rzymskiego opierały się głównie na fragmentach kodeksu justyniańskiego ${ }^{56}$. Andrzej Marquart przeprowadził analizę regulacji prawa kanonicznego $\mathrm{w}$ zakresie sukcesji testamentowej i odniósł ją do europejskiej praktyki prawnej ${ }^{57}$. Nie pominął w swych studiach prawa Wielkiego Księstwa Litewskiego, rozumianego jako Statut Wielkiego Księstwa Litewskiego ${ }^{58}$. Niewątpliwie wszystkie poruszane w dysertacji wątki miały swoje odniesienia do prawa rzymskiego, lecz przeważała w niej materia odnosząca się do obowiązującego prawa współczesnego. Wszelkie instytucje prawa spadkowego $\mathrm{w}$ zakresie dziedziczenia testamentowego i beztestamentowego zostały poddane historyczno-prawnej analizie ${ }^{59}$.

Kolejnym doktorem obojga praw został Józef Butkiewicz Popuciewicz na podstawie dysertacji Assertiones ex iurisprudentia ecclesiastica de iure non scripto, iure personarum, et immunitate ecclesiastica ${ }^{60}$. Tytuł rozprawy można tłumaczyć jako Kościelne twierdzenia jurydyczne, z mocy prawa nie spisane, prawa osób i immunitet kościelny. Obejmowała ona swym zakresem instytucje prawa kanonicznego ${ }^{61}$. Autor dysertacji jedynie śladowo odnosił swoje rozwa-

${ }_{55}$ Zob. A. Guarino: La forma orale e la forma scritta nel testamento romano. In: Studi in onore di Pietro de Francisci. Vol. 2. Milano 1956, s. 53-71.

${ }^{56}$ C.6.23.21 i C.6.22.8.

${ }^{57}$ A. Marquart: Dissertatio juridica e jure canonico, civili et Regio Poloniae Magniq[ue] Ducatus Lithuaniae nec non Saxonico et municipali Magdeburgensi. Vilnae 1647, s. 3.

${ }^{58}$ Prawdopodobnie miał na myśli III statut litewski zatwierdzony na sejmie koronacyjnym w 1588, zachowujący w pełni odrębność systemu prawnego Litwy.

${ }^{59}$ Założenia rozprawy zostały omówione w artykule — zob. P. Niczyporuk: Dissertatio juridica e jure canonico, civili et Regio Poloniae Magniq[ue] Ducatus Lithuaniae nec non Saxonico et minicipali Magdeburgensi Andrzeja Marquarta, Vilnae 1647, pierwszym doktoratem z zakresu komparatystyki prawniczej w Akademii Wileńskiej. W: Meandry prawa - teoria i praktyka: księga jubileuszowa prof. zw. dra hab. Mieczysława Goettela. Red. E.W. Pływaczewski, J. Bryk. Szczytno 2017, s. 351-366.

${ }^{60}$ Assertiones ex iurisprudentia ecclesiastica de iure non scripto, iure personarum, et immunitate ecclesiastica, sub felicissimis auspiciis Illustrissimi Domini D[omino] Casimiri Leonis Sapieha, Procancellarii M[agnique] D[ucatus] L[ithuaniae], Stonim, Volpen, Luboszan etc etc etc Gubernatoris, / per Iosephum Butkiewicz Popuciewicz, Art et Philosophiae Magistrum, Iuris Utriusq[ue] Auditorem publica disputatione propugnatae; praesidente Nobili et Clarissimo et Magnifico D[omino] Alexandro Aarone Olizarovvski, Juris utriusq[ue], Doctore Principis Neoburgensis Consiliario Iuris Canonici Ordinario Professore, in Alma Academia Vilnensi Soc. [ietatis] Iesu die [30] mense [Iunio] Anno Domini MDCXLVII [1647].

${ }^{61}$ P. Niczy poruk: Assertiones ex Jurisprudentia Aarona Aleksandra Olizarowskiego rozprawa, która nigdy nie powstała. W: Ustrój państwa, myśl polityczno-prawna, wspótczesne 
żania do prawa cywilnego (rzymskiego) celem porównania, czy traktując ten zabieg jako próbę głębszego uzasadnienia swych twierdzeń.

Również praca zatytułowana Decisio Controversiae Juris Canonici autorstwa Józefa Konstantynowicza ${ }^{62}$ dotyczyła prawa kanonicznego. Przedmiotem dysertacji Sporne decyzje w prawie kanonicznym ${ }^{63}$ były kontrowersje w małżeństwie wynikające z kanonicznego porządku prawnego ${ }^{64}$. Rozprawa doktorska obroniona na Wydziale Prawa Akademii Wileńskiej stała się podstawą do nadania jej autorowi doktoratu utriusque iuris ${ }^{65}$.

O Janie Markwarcie, autorze De damno injuriae, mamy bardzo skąpe informacje biograficzne. Nasza wiedza w tej materii sprowadza się jedynie do danych zawartych na stronie tytułowej obronionej dysertacji. Jan Markwart uzyskał stopień magistra w zakresie nauk wyzwolonych i filozofii (A[rt]a[s] L[ibera]-l[es] et Philosophiae Magister) oraz doktorat utriusque iuris ${ }^{66}$. Natomiast jego promotor był pierwszym dziekanem Wydziału Prawa Akademii Wileńskiej ${ }^{67}$.

Dysertacja Jana Markwarta De damno injuriae składa się ze wstępu, niewydzielonego żadną jednostką redakcyjną, oraz 29 niewielkich rozdziałów. Autor rozprawy zastosował ciekawy zabieg redakcyjny, który, jego zadaniem, miał ułatwić zrozumienie problematyki związanej z wyrządzeniem bezprawnej szkody. Nie tylko we wstępie, ale także w jednostkach redakcyjnych opatrzonych rzymskimi cyframi od I do VI, Jan Markwart zawarł wiadomości będące wprowadzeniem do właściwej tematyki dysertacji. Przeprowadził tam rozważania o wpływie armii i prawa na należytą ochronę państwa. Swoje wywody autor

systemy rząów: prace ofiarowane profesorowi zw. nauk prawnych Adamowi Jamrozowi z okazji Jego jubileuszu. Red. S. Bożyk, A. Olechno. Białystok 2018, s. 705-714.

${ }^{62}$ Decisio controversiae iuris canonici, sub felicissimis auspiciis Illustrissimi Domini D[omino] Casimiri Leonis Sapieha, M[agnique] D[ucatus] L[ithuaniae] Procancellarii, Stonimensis, Volpensis, Luboszanensis etc Gubernatoris, Facultatis Iurium in Alma Academia Vilnensi Soc[ietatis] Iesu munificentissimi Fundatoris / a Iosepho Konstantynowicz, Artium et Philosophiae Magistro, Sacrae Teologiae et Iuris Utr[usque] Auditore, nec non Academicarum Disputationum Moderatore, Publice Disputationi Proposita, praesidente Clarissimo et Magnifico D[omi]no Alexandro Aarone Olizarowski Iuris Utriusq[ue] Doctore, Serenissimi Principis Neoburgensis Consiliario et Canonum Ordinario Professore in Alma Acad[emia] Vilnen[si] S.[ocietatis] I[esu], Vilnae [Vilnius], Typis Academiciis S.[ocietatis] Iesu [1647].

${ }^{63}$ „Kontrowersje $w$ małżeństwie” — tak tłumaczył tytuł rozprawy Mikołaj Tarkowski (Idem: Wydział Prawa..., s. 28, szczególnie przyp. 55). Z wielkim prawdopodobieństwem można uznać, że zaczerpnął go od Józefa Bielińskiego (J. Bieliński: Uniwersytet Wileński... T. 3..., s. 442).

${ }^{64}$ P. Niczy poruk: Aaron Aleksander Olizarowski..., s. 190.

${ }^{65}$ Iuris Utr[usque] Auditore - J. Konstantynowicz: Decisio controversiae juris canonici. Vilniae 1647, s. 1.

${ }^{66}$ I. Marquart: Dissertatio juridica..., s. 1.

${ }^{67}$ L. Piechnik: Dzieje Akademii Wileńskiej..., s. 169. Zob. także: J. Bieliński: Uniwersytet Wileński... T. 2..., s. 476; S. Kot: Aaron Aleksander Olizarowski..., s. 7; J. Wisłocki: Prawo rzymskie..., s. 52. Por. J. Kodrębski: Prawo rzymskie w Polsce XIX wieku. Łódź 1990, s. 32; P. Niczy poruk: Nauczanie prawa rzymskiego..., s. 152 i nast. 
De damno injuriae rozpoczął od przywołania, na pierwszej stronie wstępu, łacińskiej paremii: salus populi suprema lex esto ${ }^{68}$. Jego zdaniem ta fundamentalna zasada, pochodząca $\mathrm{z}$ ustawy XII tablic, stanowiła gwarant należytego sprawowania władzy. Jan Markwart nie określił, w której tablicy Lex duodecimo tabularum owa paremia miałaby się znajdowaćc ${ }^{69}$. Tę fundamentalną zasadę odwołującą się do powinności obywateli wobec państwa, znamy z przekazu Cycerona w brzmieniu: ollis salus populi suprema lex esto ${ }^{70}$. Jan Markwart przywołał rzekomy fragment ustawy XII tablic ku przestrodze rządzących, uważając, że stanowiła ona gwarant należytego sprawowania władzy. Nakaz działania dla dobra wspólnego, dla współobywateli i całego państwa nie tylko miał istotne znaczenie w czasach starożytnych, ale także zachował swą aktualność w Rzeczypospolitej szlacheckiej XVII w. ${ }^{71}$.

Jan Markwart, w pierwszych sześciu początkowych jednostkach redakcyjnych, dość obficie cytował fragmenty z konstytucji justyniańskich Imperatoriam maiestatem oraz Tanta ${ }^{72}$. Oprócz nich, na poparcie swoich twierdzeń, przytaczał urywki z kodyfikacji justyniańskiej, głównie z Digestów. Świadczy to nie tylko o znajomości cytowanych fragmentów, ale także całej kodyfikacji justyniańskiej. Dołączone do rozprawy przypisy odwoływały się w znacznej mierze do Digestów, Kodeksu i Instytucji oraz łacińskiej literatury nieprawniczej. Sposób cytowania przyjęty przez J. Markwarta wymagał znajomości wszystkich tytułów z Digestów oraz pierwszych zdań wielu konstytucji cesarskich.

Bardzo ciekawe, z punktu widzenia romanisty, były wywody autora De damno injuriae w czwartej jednostce redakcyjnej o źródłach prawa i ich ewolucji od okresu królewskiego, poprzez republikę, na cesarstwie kończąc. Jan Markwart przedstawiał w bardzo plastyczny sposób okoliczności powstania ustawy XII tablic i udział w tym procesie komisji dziesięciu mężów. Wywody piątej i szóstej jednostki redakcyjnej odnosiły się do kodyfikacji justyniańskiej ${ }^{73}$. Jan Markwart cytował tam konstytucje Justyniana, w których cesarz przedstawił cele leżące u podstaw podjęcia się prac kodyfikacyjnych.

Autor De damno injuriae właściwe rozważania odnośnie do szkody i odpowiedzialności odszkodowawczej prowadził od części VII swej dysertacji. Także i w tej części pracy dość często cytował obszerne fragmenty kodyfikacji

68 „Dobro ludu niech będzie najwyższą ustawą” (tłumaczenie Autora).

${ }^{69}$ I. Marquart: Dissertatio juridica..., s. 2.

${ }^{70}$ Cic., De legibus 3,3,8.

${ }^{71}$ M. Wichowa: Klasycyzm jako element światopoglądu twórców literatury polskiego baroku. „Wschodni Rocznik Humanistyczny” 2010-2011, T. 7, s. 75; A. Bryk: Konstytucjonalizm. Od starożytnego Izraela do liberalnego konstytucjonalizmu amerykańskiego. Kraków 2013, s. 143, przyp. 192.

${ }^{72}$ Constit. imperatoriam maiestatem 1; Tanta, de confirm. Por. A. Agudo Ruiz: Justiniano y la reforma de los estudios jurídicos. „REDUR” (Revista electrónica de derecho Universidad de La Rioja) 2012, Vol. 10, s. 6 i nast.

${ }^{73}$ I. Marquart: Dissertatio juridica..., s. 9-10. 
justyniańskiej. W szczególności przytaczał pisma jurystów rzymskich odnoszące się do lex Aquilia, które kompilatorzy umieścili w Digestach. Również w celu uzasadnienia swoich poglądów na szkodę i odpowiedzialność odszkodowawczą powoływał się na rzymską literaturę nieprawniczą ${ }^{74}$. Podobnie jak we wstępnych fragmentach rozprawy, tak i w dalszej jej części, Markwart rzadko sięgał po nowele wydawane przez cesarza Justyniana ${ }^{75}$.

\section{Wnioski}

W latach 1644-1655 Akademia Wileńska i jej Wydział Prawa przeżywały okres dynamicznego rozwoju. Dopiero najazd moskiewski i potop szwedzki przerwały rozkwit uczelni i jej istotnego fakultetu. Od 1647 r. na Wydziale Prawa Akademii Wileńskiej ukazało się kilka publikacji pracujących tam profesorów oraz wypromowanych doktorów obojga praw (utriusque iuris). Bardzo istotne znaczenia dla studentów Wydziału Prawa miała wydana w roku 1648 rozprawa Benedykta de Soxo, rektora Akademii Wileńskiej, pod tytułem: Claves juris. Praca ta nie została napisana przez romanistę, ale zawierała liczne odniesienia do prawa cywilnego (rzymskiego), w szczególności do kodyfikacji justyniańskiej. Jej autor niewątpliwie był wybitnym specjalistą z zakresu prawa kanonicznego, prawdopodobnie jednym $\mathrm{z}$ czterech pierwszych profesorów Wydziału Prawa Akademii Wileńskiej. Claves juris miało istotne znaczenie dla prawa cywilnego (rzymskiego) ze względu na swą objętość i treść. Benedykt de Soxo zawarł w niej pojęcia, podziały, źródła prawa kanonicznego, cywilnego (rzymskiego) oraz miejscowego. Ważne miejsce w jego publikacji zajmowała interpretacja prawna, autorytet uczonych oraz formułki, zwroty, klauzule czy wyrazy techniczne. Wszystkie poruszone w rozprawie problemy miały swoje romanistyczne korzenie.

Aaron Aleksander Olizarowski, profesor na Wydziale Prawa Akademii Wileńskiej, wydał w 1651 r. w Gdańsku dzieło swego życia: De politica hominum societate. Co prawda rozprawa ta stanowiła systematyczny wykład wiedzy o społeczeństwie i państwie, ale w jej treści odnajdujemy liczne odniesienia romanistyczne. Najwięcej zagadnień mających swoje korzenie w prawie rzymskim zawarł w księdze pierwszej - De Domo. Tam Olizarowski omówił zagadnienia związane z małżeństwem, rodziną oraz niewolnictwem. Kwestie dotyczące wieku nupturientów, secundae nuptiae wdowy oraz obowiązków małżeńskich

${ }^{74}$ I. Marquart cytuje Cycerona (ibidem, s. 15), Owidiusza (ibidem, s. 26), czy Senekę (ibidem, s. 16).

${ }^{75}$ Chociażby na Nov. 140. Zob. I. Marquart: Dissertatio juridica..., s. 17. 
mają swoje źródło w prawie rzymskim, o czym zaznaczył Olizarowski na kartach swojej dysertacji. Także relacje prawne pomiędzy rodzicami a dziećmi to zagadnienia znane prawu rzymskiemu. Szczególnie władza ojcowska i granice wieku były sferami prawnymi znanymi i rozwijanymi od czasów starożytnych.

W księdze drugiej i trzeciej De politica hominum societate możemy dostrzec mniej wątków romanistycznych niż zawierała pierwsza z nich. Jest to zrozumiałe ze względu na tematykę tychże części dzieła Olizarowskiego. Jednakże wszelkie odniesienia do prawa rzymskiego w treści dysertacji świadczyły o dobrej znajomości autora De politica hominum societate instytucji prawa rzymskiego. Umiał je umiejętnie wykorzystać, mając na względzie ich ewolucje na przestrzeni dziejów. Co prawda De politica hominum societate nie jest dziełem wyłącznie romanistycznym, ale udział w nim zagadnień związanych z prawem rzymskim był znaczny.

Tylko doktorat Jana Marquarta z 1650 r. o tytule De damno injuriae został napisany wyłącznie na podstawie prawa cywilnego (rzymskiego). Był jedyną rozprawą z tej materii prawnej w Akademii Wileńskiej w latach 1644-1655. Pozostałe doktoraty $\mathrm{z}$ tego okresu miały charakter prawno-porównawczy lub napisano je, opierając się na kanonicznym porządku prawnym. Dysertacja Jana Markwarta zawierała omówienie problematyki związanej z wyrządzeniem bezprawnej szkody. Zawierała ciekawe wiadomości z zakresu prawa rzymskiego będące wprowadzeniem do właściwej tematyki dysertacji. Autor De damno injuriae w ciekawy sposób przedstawił historyczny rozwój źródeł prawa w starożytnym Rzymie. We właściwej części dysertacji Jan Markwart odniósł się do powstania szkody i odpowiedzialności odszkodowawczej, a także do sposobu zastosowania odpowiednich przepisów lex Aquilia. Na poparcie swych wywodów powołał się na źródła prawa oraz na rzymską literaturę nieprawniczą. Była to więc jedyna publikacja, która wyłącznie wchodziła w zakres prawa rzymskiego. Jej autor był romanistą i jego praca stanowiła świadectwo tego faktu.

\section{Bibliografia}

\section{Źródla}

Akt fundacji i uposażenia Akademii Wileńskiej przez Waleriana Protasiewicza, biskupa wileńskiego uczyniony 24 sierpnia 1578 roku, a potwierdzony przez króla Stefana Batorego, naprzód w Wilnie 1 kwietnia 1579 roku, potem zaś za zgoda wszystkich stanów powtórnie na sejmie w Warszawie 23 lutego 1585 roku. W: M. Baliński: Dawna Akademia Wileńska. Petersburg 1862.

Archivum Romanum Societatis Iesu (ARSI). Annuae Litterae Collegii Vilnensis Societatis Iesu 1655, dział Lithuanica 40 f. 92. 
Archivum Romanum Societatis Iesu, dział Lithuanica 36 f. 274v Przywilej króla Stefana (Batorego) dany jezuitom kolegium wileńskiego, we Lwowie 7 lipca roku 1578, na ustanowienie Akademii w Wilnie, gabinetowy, tak zwany kieszonkowy, potrzebujący potwierdzenia stanów Rzeczypospolitej na sejmie [...]. W: M. Baliński: Dawna Akademia Wileńska. Petersburg 1862.

Archiwum Polskiej Akademii Nauk, maszyn. III-83, j. 9. Materiaty Janiny Iwaszkiewicz, Uniwersytet Wileński. Teksty i wypisy źródtowe dotyczace Uniwersytetu Wileńskiego.

Assertiones ex iurisprudentia ecclesiastica de iure non scripto, iure personarum, et immunitate ecclesiastica, sub felicissimis auspiciis Illustrissimi Domini D[omino] Casimiri Leonis Sapieha, Procancellarii M[agnique] D[ucatus] L[ithuaniae], Stonim, Volpen, Luboszan etc etc etc Gubernatoris, / per Iosephum Butkiewicz Popuciewicz, Art et Philosophiae Magistrum, Iuris Utriusq[ue] Auditorem publica disputatione propugnatae; praesidente Nobili et Clarissimo et Magnifico D[omino] Alexandro Aarone Olizarovvski, Juris utriusq[ue], Doctore Principis Neoburgensis Consiliario Iuris Canonici Ordinario Professore, in Alma Academia Vilnensi Soc. [ietatis] Iesu die [30] mense [Iunio] Anno Domini MDCXLVII [1647].

Bulla Grzegorza XIII Najwyższego Pasterza. Wyjęta z rzymskiego bullariusza. C. II. W: M. Baliński: Dawna Akademia Wileńska. Petersburg 1862.

Bultarum, diplomatum et privilegiorum sanetorum Romanorum Pontificum Taurinensis editio. Vol. 8. Torinas 1863.

Claves iuris Academicis Vilnensibus a R. P. Benedicto de Soxo S. I. sacrae theologiae doctore et Academiae vicecancellario porrectae. Vilniae Typis Academicis Societatis Iesu 1648.

Decisio controversiae iuris canonici, sub felicissimis auspiciis Illustrissimi Domini D[omino] Casimiri Leonis Sapieha, M[agnique] D[ucatus] L[ithuaniae] Procancellarii, Stonimensis, Volpensis, Luboszanensis etc Gubernatoris, Facultatis Iurium in Alma Academia Vilnensi Soc[ietatis] Iesu munificentissimi Fundatoris / a Iosepho Konstantynowicz, Artium et Philosophiae Magistro, Sacrae Teologiae et Iuris Utr[usque] Auditore, nec non Academicarum Disputationum Moderatore, Publice Disputationi Proposita, praesidente Clarissimo et Magnifico D[omi]no Alexandro Aarone Olizarowski Iuris Utriusq[ue] Doctore, Serenissimi Principis Neoburgensis Consiliario et Canonum Ordinario Professore in Alma Acad[emia] Vilnen[si] S.[ocietatis] I[esu], Vilnae [Vilnius], Typis Academiciis S.[ocietatis] Iesu [1647].

Dissertatio iuridica de damno iniuriae, quam proside Nobili et Clarissimo D[omino] Simone Dilger Morenweisensi Bavaro, I[uris] U[triusque] Doctore, et in Alma Universitate Vilnensi Soc[ietatis] Iesu Pandectarum Professore Ordinario defendendam suscepit pro obtinenda Doctoratus in eadem Facultate Laurea Ioannes Marquart A[rt]a[s] L[Ibera]l[es] et Philosophiae Magister Iuris Utriusque Auditor, Vilnae [Vilnius], Typis Academiciis S[ocietatis] I[esu]. Anno D[omin]ai. M.DC.L.(1650) Mense Maii Die.

Dissertatio iuridica e iure canonico, civili et regio Poloniae, Magniq[ue] Ducatus Lithuaniae nec non Saxonico et municipali Magdeburgensi decisa quam sub felicissimis auspiciis Illustrissimi Domini D[omino] Casimiri Leonis Sapieha, M[agnique] D[ucatus] L[ithuaniae] Procancellarii, Stonimensis, Volpensis, Luboszanensis etc Gubernatoris in Alma Universitate Vilnensi Soc[ietatis] Jesu, Facultatis Iuridicae 
Fundatoris, praeside Nobili et Clarissimo D[omi]n[o] Joanne Georgio Schaver de Augenburg I[uris] U[triusque] Doctore et in eadem Universitate S[anti]s[ime] Canon[um] Ordinario Professore, / defendendam suscepit Andreas Marquart, AA.[Artium] LL.[Liberalium] et Philosophiae Magister et I[uris] U[triusque] Auditor. Vilnae [Vilnius], Typis Academicis Soc[ietatis] Iesu, Anno Domini MDCXLVII [1647]. die [22] Iunii.

List Aarona Aleksandra Olizarowskiego do Kazimierza Lwa Sapiehy z 26 września 1644 [znajdujący się w Bibliotece Czartoryskich, którego tłumaczenie publikuje]: L. Piechnik: Dzieje Akademii Wileńskiej. T. 2: Rozkwit Akademii Wileńskiej w latach 1600-1655. Rzym 1982.

Przywilej Władysława IV dany Jezuitom Kolegium Wileńskiego, w Warszawie, w roku 1641, dnia 11 października, na publiczne wykładanie w Akademii Wileńskiej prawa kanonicznego i cywilnego oraz medycyny. W: M. Baliński: Dawna Akademia Wileńska. Petersburg 1862.

Tractatus de venerabili Eucharistiae Sacramento..., Kungliga Biblioteket w Sztokholmie, Rkp. A 817 s. 36-127.

\section{Literatura}

Agudo Ruiz A.: Justiniano y la reforma de los estudios jurídicos. „REDUR” (Revista electrónica de derecho Universidad de La Rioja) 2012, T. 10.

Baliński M.: Dawna Akademia Wileńska. Petersburg 1862.

Baliński M.: 1578-1803-1919. „Dziennik Wileński” 1919, T. 145.

Bednarski S.: Dwieście lat Wileńskiej Akademii Jezuickiej 1570-1773. W: Pamiętnik VI powszechnego zjazdu historyków polskich w Wilnie 17-20 września 1935 r. Red. F. Podhorodecki. Cz. 1. Lwów 1935.

Bednarski S.: Geneza Akademii Wileńskiej. W: Księga pamiątkowa ku uczczeniu CCCL rocznicy założenia i X wskrzeszenia uniwersytetu Wileńskiego. T. 1. Wilno 1929.

Berger A.: Encyclopedic Dictionary of Roman Law. Philadelphia 1953 (przedruk 1991).

Bieliński J.: Uniwersytet Wileński (1579-1831). T. 2-3. Kraków 1900.

Bogusis V.: Medicina Vilniaus Universitete XVI-XVII amziuje. „Mokslas ir Gyvenimas" 1979, T. 10.

Bryk A.: Konstytucjonalizm. Od starożytnego Izraela do liberalnego konstytucjonalizmu amerykańskiego. Kraków 2013.

Burdesse A.: Sulla capacita intellettuale degli impuberes in diritto classico. „Archivio Giuridico Filippo Serafini”" 1956, T. 150.

De Dominicis La M.: I coloni ,adscripticii” nella legislazione di Giustiniano. In: Studi in onore di Emilio Betti. Vol. 3. Milano 1962.

Encyklopedia wiedzy o jezuitach na ziemiach Polski $i$ Litwy 1564-1995. Oprac. L. Grzebień. Kraków 2004.

Estreicher K.: Bibliografia polska. Cz. 3: Bibliografia wieków XV-XVIII w układzie abecadłowym. T. 29. Warszawa 1977, https://www.estreicher.uj.edu.pl/staropolska/ indeks/wpis/?id=46539\&fileId=0115. 
Filozofia i myśl społeczna XVII wieku. Cz. 1. Red. Z. Ogonowski. Warszawa 1979.

G miterek H.: Promocje doktorskie w Akademii Zamojskiej. W: W kręu akademickiego Zamościa. Red. H. Gmiterek. Zamość 1996.

Grzebień L.: Soxo (Sojo) Benedykt (Benito). W: Polski stownik biograficzny. T. 41. Kraków 2002.

Guarino A.: La forma orale e la forma scritta nel testamento romano. In: Studi in onore di Pietro de Francisci. T. 2. Milano 1956.

Historia nauki polskiej. Red. B. Suchodolski. T. 6: Dokumentacja bio-bibliograficzna. Oprac. L. Hajdukiewicz. Wrocław 1974.

Impallomeni G.: Persona fisica. Diritto romano. „Novissimo Digesto Italiano” 1965, T. 12 = Scritti di diritto romano e tradizione romanistica, Padova 1996\}.

Janowski L.: Historiografia Uniwersytetu Wileńskiego. Cz. 1. Wilno 1921.

Jarra E.: Aleksander Olizarowski, jako filozof prawa. W: Ksiega pamiatkowa celem uczczenia 350. rocznicy założenia Uniwersytetu Stefana Batorego w Wilnie. Warszawa 1931.

Jedynak S.: Etyka w Polsce. Stownik pisarzy. Wrocław 1986.

Kodrębski J.: Prawo rzymskie w Polsce XIX wieku. Łódź 1990.

Kolendo J.: Kolonat w Afryce rzymskiej w I-II wieku I jego geneza. Warszawa 1962.

Kot S.: Aaron Aleksander Olizarowski, profesor prawa Akademii Wileńskiej. W: Księga pamiatkowa ku uczczeniu CCCL rocznicy założenia i X wskrzeszenia Uniwersytetu Wileńskiego. Wilno 1929.

Kuleczka G.: Dzieci w systemie prawnym starożytnego Rzymu. „Meander” 1979, z. $5-6$.

Kuleczka G.: Prawo rzymskie epoki pryncypatu wobec dzieci pozamatżeńskich. Wrocław-Warszawa-Kraków 1969.

Lyavshuk V.: Stephan Bathory and the Jesuitsin Grodno: First Attempt to Found a Collegium. „Medieval and Early Modern Studies for Central and Eastern Europe" 2010, T. 2.

Łapicki B.: La transformation de la nature juridique du colonat romain. In: Studi in onore di Edoardo Volterra. Vol. 3. Milano 1971.

Mandziuk J.: Księgozbiór Melchiora kardynała Diepenbrocka, księcia-biskupa wroclawskiego (1798-1853). „Saeculum Christianum” 2004, T. 11, nr 1.

Mirković M.: The Later Roman Colonate and Freedom. Philadelphia 1997.

Niczyporuk P.: Aaron Aleksander Olizarowski profesorem prawa Akademii Wileńskiej. „Miscellanea Historico-Iuridica” 2015, z. 2.

Niczyporuk P.: Assertiones ex Jurisprudentia Aarona Aleksandra Olizarowskiego rozprawa, która nigdy nie powstała. W: Ustrój państwa, myśl polityczno-prawna, wspótczesne systemy rzadów: prace ofiarowane profesorowi zw. nauk prawnych Adamowi Jamrozowi z okazji Jego jubileuszu. Red. S. Bożyk, A. Olechno. Białystok 2018.

Niczyporuk P.: Dissertatio juridica e jure canonico, civili et Regio Poloniae Magniq[ue] Ducatus Lithuaniae nec non Saxonico et minicipali Magdeburgensi Andrzeja Marquarta, Vilnae 1647, pierwszym doktoratem z zakresu komparatystyki prawniczej w Akademii Wileńskiej. W: Meandry prawa - teoria i praktyka: księga jubileuszowa prof. zw. dra hab. Mieczystawa Goettela. Red. E.W. Pływaczewski, J. Bryk. Szczytno 2017. 
Niczy poruk P.: Dissertatio iuridica de damno injuriae Jana Marquarta, Vilnae 1650, pierwszym doktoratem z zakresu prawa rzymskiego $w$ Akademii Wileńskiej. W: Semperfidelis. Prace dedykowane pamięci Profesora Janusza Sondla - legendzie krakowskiego fakultetu prawniczego. Red. D. Malec, Ł. Marzec, T. Palmirski. Kraków 2017.

Niczyporuk P.: Kompetencje pater familias względem dzieci $w$ ustawach królewskich (leges regiae) w starożytnym Rzymie. W: Mężczyzna, etyka, ekonomia. Red. E. Ozorowski, R.C. Horodeński. Białystok 2011.

Niczyporuk P.: Nauczanie prawa rzymskiego w Akademii Wileńskiej. W: Wielokulturowość polskiego pogranicza. Ludzie - idee - prawo. Materiały ze Zjazdu Katedr Historycznoprawnych Augustów 15-18 września 2000 r. Red. A. Lityński, P. Fiedorczyk. Białystok 2003.

Niczy poruk P.: Promocje doktorskie obojga praw w Akademii Wileńskiej. „Miscellanea Historico-Iuridica" 2004, T. 2.

Nowak [Jurewicz] A.: Pojęcie władzy ojcowskiej w rzymskim prawie klasycznym. „Studia Prawnoustrojowe” 2002, T. 1.

Pawluk T.: Z zagadnień kanonistyki polskiej. „Prawo Kanoniczne” 1976, nr 3-4.

Petrani A.: Nauka prawa kanonicznego w Polsce w XVIII i XIX wieku. Lublin 1961.

Petrauskienè I.: Dél medicinos ir teisès katedru isteigimo Vilniaus akademijoje XVIII a. pradžioje. „Lietuvos Istorijos Metraštis” 1974 Metai, 1976.

Piechnik L.: Dzieje Akademii Wileńskiej. T. 2: Rozkwit Akademii Wileńskiej w latach 1600-1655. Rzym 1982.

Piechnik L.: Soxo (Sojo) Benedykt de. W: Słownik polskich teologów katolickich. Red. H.E. Wyczawski. T. 4. Warszawa 1983.

Plečkaitis R.: Filozofia prawa $w$ dawnym Uniwersytecie Wileńskim. W: Philosophia vitam alere. Prace dedykowane Księdzu Profesorowi Romanowi Darowskiemu SJ z okazji 70-lecia urodzin. Red. S. Ziemiański SJ. Kraków 2005.

Pyszka S.: Il diritto alla libertà personale e alla cittadinanza dei contadini polacchi e lituani in Aron Aleksander Olizarowski (1610-1659). „Forum Philosophicum” 2002, T. 7.

Rostowski S.: Lituanicarum Societatis Jesu historiarum libri decem. Recogn. J. Martinov. Parisiis 1877.

Rybicki P.: Pojęcie społeczności u pisarzy polskiego odrodzenia. „Studia i Materiały z Dziejów Nauki Polskiej”, Seria A: Historia nauk społecznych 1957, z. 1 (5).

Rybicki P.: Z dziejów polskiego arystotelizmu: De politica hominum societate Arona Aleksandra Olizarowskiego. „Studia i Materiały z Dziejów Nauki Polskiej”, Seria A: Historia nauk spotecznych 1959, z. 3.

Tamošiūnienè A.: Lietuvos sprendimai ir Naujausiuju laiku skaitytojas. „Senoji Lietuvos Literatūra" 2008, Vol. 25.

Tarkowski M.: Wydzial Prawa i Nauk Spolecznych Uniwersytetu Stefana Batorego $w$ Wilnie $w$ latach 1919-1939. Gdańsk 2015.

Tazbir J.: Thomas More in Poland. „Acta Polonia e Historica” 1976, T. 33.

Ulčinaite E.: Vilniaus akademijos profesorius A. Olizarovijus. „Mokslas ir gyvenimas" 1978, Vol. 5.

Wichowa M.: Klasycyzm jako element światopogladu twórców literatury polskiego baroku. „Wschodni Rocznik Humanistyczny” 2010-2011, T. 7. 
Wisłocki J.: Prawo rzymskie w Polsce. Warszawa 1945.

Wolfarth W.: Ascripticii w Polsce. Wrocław-Kraków 1959.

Wycisk F.: Obowiazki alimentacyjny $i$ wychowawczy w prawie rzymskim okresu królewskiego. „Roczniki Teologiczno-Kanoniczne” 1963, z. 4.

Zabłocka M.: Przemiany prawa osobowego i rodzinnego $w$ ustawodawstwie dynastii julijsko-klaudyjskiej. Warszawa 1987.

Zabłocki J.: „COnsortium ercto non cito” w „Noctes Atticae” Aulusa Gelliusa. „Prawo Kanoniczne" 1988, z. 4.

Zabłocki J.: „Postumus” w „Noctes Atticae” Aulusa Gelliusa. „Prawo Kanoniczne” 1997, z. $1-2$.

Zabłocki J.: Appunti sull' ,officium iudicis” nelle „,Noctes Atticae”. In: Au-delà des fontierès. Mélanges de droit romain offers à Witold Wołodkiewicz. Vol. 2. Varsovie 2000.

Zabłocki J.: Kompetencje „patres familias” i zgromadzeń ludowych $w$ świetle „Noctes Atticae” Aulusa Gelliusa. Warszawa 1990.

Zabłocki J.: Rodzina rzymska w świetle „Noctes Atticae” Aulusa Gelliusa. W: Rodzina $w$ społeczeństwach antycznych $i$ wczesnym chrześcijaństwie. Literatura, prawo, epigrafika, sztuka. Red. J. Jundziłł. Bydgoszcz 1995.

Zabłocki J.: Rozważania o procesie rzymskim w „Noctes Atticae” Aulusa Gelliusa, Warszawa 1999.

Zabłocki J.: Rzymskie Studia Aulusa Gelliusa. „Acta Universitatis Wratislaviensis”. Prawo 2008, T. 305: Studia historycznoprawne. Tom poświęcony pamięci Profesora Edwarda Szymoszka. Red. A. Konieczny.

Zabłocki J.: Talion w świetle „Noctes Atticae” Aulusa Gelliusa. „Prawo Kanoniczne” 1995, z. $3-4$.

Zabłocki J.: The Image of a Roman Family in „Noctes Atticae” by Aulus Gellius, „Pomoerium. Studia et Commentarii Ad Orbem Classicum Spectantia” 1996, T. 2.

Zabłocki J.: The Intellectual Background of Aulus Gellius. „Diritto@Storia. Rivista internazionale di Scienze Giuridiche e Tradizione Romana" 2007, T. 6.

Zabłocki J.: Ze studiów filozofii Aulusa Gelliusa w Atenach. W: Profesorowi Janowi Kodrębskiemu in memoriam. Red. A. Pikulska-Robaszkiewicz. Łódź 2000.

Załęski S.: Jezuici w Polsce. T. 2: Jezuiccy pisarze 1608-1648. Lwów 1901.

Piotr Niczyporuk

\section{Romanistische Publikationen an der Vilniuser Akademie in den Jahren 1644-1655}

Schlüsselwörter: Juristische Fakultät der Vilniuser Akademie, Romanisten, Rechtsprofessoren, Doktoren beiderlei Rechts (utriusque iuris), römisches Recht

Zusammenfassung: In den Jahren 1644-1655 erschienen an der Juristischen Fakultät der Vilniuser Akademie einige Publikationen von dort tätigen Professoren und promovierten Doktoren beiderlei Rechts (utriusque iuris). Ein Teil davon betraf das römische Recht. In der Dissertation von Benedicto de Soxo Claves juris sind zahlreiche romanistische Motive zu finden. Der Rektor 
der Vilniuser Akademie diskutierte Begriffe, Redewendungen und Prinzipien, die im römischen Recht verankert sind. Auch Überlegungen über Rechtsquellen, deren Auslegung oder Rechtswissenschaften hatten ihre romanische Wurzeln.

Aaron Alexander Olizarowski, Professor an der Juristischen Fakultät der Vilniuser Akademie, bezog sich mehrmals in seinem 1651 in Danzig veröffentlichten Werk De politica hominum societate auf das römische Recht. Die meisten romanistischen Themen wurden im ersten Buch - De Domo - bei der Erörterung von Fragen, die mit der Ehe und Familie verbunden waren, gefunden.

Im Jahr 1650 schrieb Jan Marquarta seine Dissertation zum römischen Recht mit dem Titel De damno injuriae, die in den Jahren 1644-1655 an der Vilniuser Akademie die einzige Dissertation zu diesem Thema war. Obwohl das Werk Schäden und Schadensersatzhaftung betrifft, präsentierte sein Autor zusätzlich die historische Entwicklung der Rechtsquellen im antiken Rom. Der Inhalt und die Struktur der Dissertation zeugen von der guten romanistischen Vorbereitung ihres Verfassers.

Die Arbeiten, die sich inhaltlich auf das römische Recht beziehen und in der Anfangsperiode der Tätigkeit der Juristischen Fakultät der Vilniuser Akademie erschienen, zeugen von seiner wichtigen Rolle in der Wissenschaft und im Lehren im universitären Jurastudium.

Piotr Niczyporuk

\section{Romanistic publications in the Vilnius Academy in the years 1644-1655}

Keywords: Faculty of Law of the Vilnius Academy, romanists, professors of law, doctors of both laws (utriusque iuris), Roman law

Summary: In the years $1644-1655$ the Faculty of Law of the Vilnius Academy published several publications of professors working there and promoted doctors of both laws (utriusque iuris). Some of them covered Roman law. The dissertation of Benedict de Soxo, Claves juris, contains numerous Romanistic motifs. The Rector of the Vilnius Academy discussed terms, phrases and principles rooted in Roman law. Also, considerations concerning the sources of law, its interpretation or the teaching of law had their romanistic roots.

Aaron Aleksander Olizarowski, professor at the Faculty of Law of the Vilnius Academy, in his work De politica hominum societate, published in Gdańsk in 1651, made numerous references to Roman law. Most of the romanistic themes were included in the first book, De Domo, when discussing issues related to marriage and family.

In 1650 Jan Marquarta wrote a dissertation on Roman law entitled De damno injuriae, which was the only dissertation on this legal matter at the Vilnius Academy in the years 1644-1655. Although the work concerned damage and liability for damages, its author additionally presented the historical development of sources of law in ancient Rome. The content and structure of the dissertation testifies to the good romanistic background of its author.

The works referring in their content to Roman law, in the initial period of functioning of the Faculty of Law of the Vilnius Academy, testify to its important role in science and teaching at university law studies. 